\title{
POSSIBLE THREATS, OBSTACLES AND LIMITATIONS IN IMPLEMENTATION OF BUSINESS INTELLIGENT IN BULGARIAN SMALL AND MEDIUM-SIZED ENTERPRISES Melina Neykova ${ }^{1}$
}

Received: 03.09.2020, Accepted: 09.09.2020

\begin{abstract}
Intelligent information systems for business analysis are a strategic tool that enables different sized organizations to analyze and manage huge amounts of business information. Therefore, in recent years, the information and communication technology industry continuously generates intelligent solutions that perform fast retrieval, transformation, organization, analysis and summarization of large amounts of data. Simultaneously the type and number of business intelligent solutions on the market is steadily growing, which in turn can affect the possibility of failure in the process of perception and implementation of the chosen solution in Bulgarian small and mediumsized enterprises. In this sense, the analysis performed in the presented article is valuable for Bulgarian managers, as it is aimed at studying the factors - the most common threats, obstacles and limitations that affect the process of introducing modern business intelligent systems as part of the policy for improvement of the existing information and communication system in Bulgarian small and medium-sized enterprises.
\end{abstract}

Keywords: information and communication technologies (ICT), business intelligence systems (BIS), small and medium-sized enterprises (SMEs),

JEL Codes: C80, C88, L86, M10, M15

\section{Introduction}

Well-established good practices among organizations worldwide show that the successful management of the business community increasingly depends on the adoption of effective strategies related to the improvement of the implemented and functioning information and communication infrastructure (ICT), as well as the integration of innovative, adaptive, flexible and adaptable platforms and solutions (Neykova \& Miltchev, 2019). Unfortunately, in practice, as a result of the growing mobility of enterprises and the automated activities performed on the Internet or the intranet/extranet, large generated data flows are

${ }^{1}$ University of Forestry, Department of Computer Systems and Informatics, Researcher, e-mail: mneykova@ltu.bg,ORCID ID: https://orcid.org/0000-0003-1016-962X 
often not processed efficiently, so that their analysis can lead to a clear assessment of the situation and the priorities for the development of the organization, as well as to the planning and extrapolation of the data. In response to this, in recent decades the industry of information and communication technologies (ICT) continuously generates applications and technological tools that can be used for data management, for studying models and trends in data and information, and for business intelligence (BI). In order to meet the set of consumer needs for business analysis of organizations, BI software companies in the market develop different products, each of which is designed to support one of the five categories shown in Figure no. 1. (MicroStrategy, 2013)

Figure no. 1. The categories of BI applications

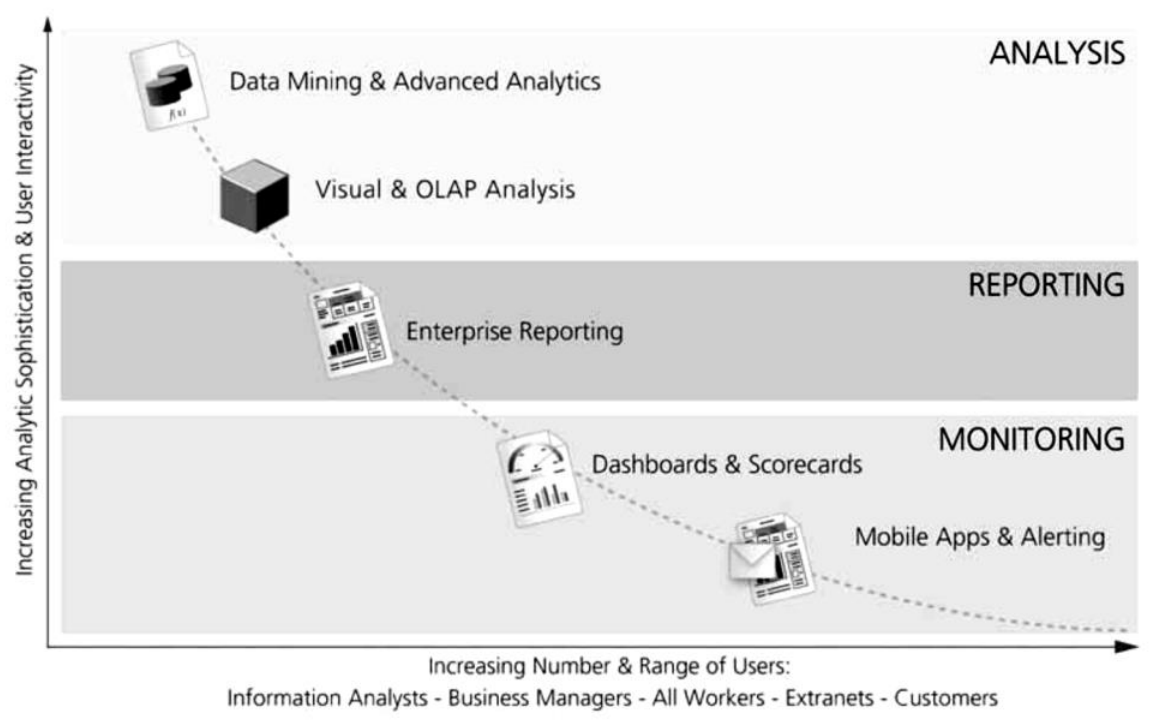

Source: MicroStrategy, 2013

Numerous reports and academic studies have examined a trend showing business intelligence solutions (BIS) as an important element present in the list of priority technologies of different sized organizations. This is because company managers, as well as lower-level employees in organizations, need accurate information, analysis and visualization through various real-time business analysis software tools to properly assess the state and priorities for the development of the company and to make effective management decisions. BIS provide the management of the companies with an effective way of presenting a multidimensional description of data through tools for quick extraction, 
transformation, organization, analysis and summary of a large amount of business information (Shariat \& Hightower, 2007; Watson \& Wixom, 2007; Yeoh \& Koronios, 2010; UL-Ain et al., 2019).

In addition, the business intelligence systems support decision-making processes, they are applicable in all small and medium-sized enterprises (SMEs) and will contribute to increasing their competitiveness. Moreover, business intelligence technologies will help to create a more complete picture of the organization's development at the particular time of analysis, as well as to integrate data generated from different sources, which will help support the process of rethinking and future planning of the vision and development of the business structure. At the same time, however, this strategic tool must be coordinated and integrated with the business space and the decision-making environment used in the organization and it is exactly this proportion that is the key to the success of business intelligence (Clark at al., 2007). Therefore, the implementation of such a system will lead to the transformation of business data into valuable information and knowledge which will help the management team of professionals to take timely, informed, well-founded management decisions and actions in the context of the rapidly changing business environment worldwide. As the main purpose of business intelligence systems (BIS) is to support decision-making processes, they are applicable in all small and mediumsized enterprises (SMEs) and will contribute to increasing their competitiveness.

Given that intelligent information systems for business analysis can be considered a strategic tool for improving the ICT of the enterprise (Watson \& Wixom, 2007), which increases the innovation capacity of the organization and helps to improve the business activity, the type and number of BI solutions on the market has been constantly growing in recent years, and this affects the challenges in the process of perception and implementation of the chosen solution, as well as increases the risk of failure. This is because the development of BIS is a long process and requires serious analysis, large investments and constant changes in the functioning and adjustment of the generated results, as well as in the flexibility and perception of management teams. The good global practices show that the successful implementation of a BI system implementation project provides many advantages and opportunities for experts and company managers to make more effective timely management decisions. However, according to Farrokhi and Pokoràdi (2012), the risk of failure in the implementation of BI projects is high. In this sense, the presented analysis seeks to examine the factors - the most common threats, obstacles and constraints that affect the process of introducing modern business intelligent systems as part of 
the policy to improve the existing information and communication system of Bulgarian small and medium-sized enterprises. Such an analysis is especially valuable for Bulgarian managers, whose companies participate in the implementation of BI projects and are faced with assessing the readiness of their organizations before launching the implementation phase of the project.

2. Possible threats, obstacles and limitations in the process of BI implementation in Bulgarian SMEs

Defining the main factors that influence the process of implementation and use of BIS in Bulgarian small and medium-sized enterprises will allow the management units to look for ways to overcome them. In this sense, the managers of small and medium-sized enterprises should be aware of the pros and cons of the decision that the company will use and based on that to develop their strategy on how the implemented solution can allow them to be more flexible in managing and analyzing large amounts of data and making effective management decisions. Therefore, the creation of a comprehensive management strategy for the adoption of BIS is particularly important in the process of introducing intelligent business systems in Bulgarian SMEs. To build such a strategy it is recommended that the managers of SMEs take into account the most common threats, obstacles and limitations that may have a significant impact on the failure and/or dissatisfaction with the implementation process, as well as the actions needed to address and overcome them (Table no. 1).

Table no. 1 -Possible threats, obstacles and limitations in the process of BI implementation in Bulgarian SMEs

\begin{tabular}{|l|l|}
\hline Possible threats, obstacles and limitations & \multicolumn{1}{|c|}{ Actions needed to address them } \\
\hline $\begin{array}{l}\text { Underestimation of BIS by senior } \\
\text { management }\end{array}$ & $\begin{array}{l}\text { Raising their awareness of the advantages } \\
\text { of BIS and good practices worldwide in } \\
\text { order to understand the specific } \\
\text { advantages and the necessary change. } \\
\text { Adopting and developing a strategy by } \\
\text { the senior management for the } \\
\text { implementation and investment in the } \\
\text { process of BIS integration. }\end{array}$ \\
\hline Insufficient awareness of modern BIS & $\begin{array}{l}\text { Carrying out information research on the } \\
\text { products offered on the market. } \\
\text { Performing an analysis of good practices. } \\
\text { Benchmarking (analysis and comparison } \\
\text { with the experience of leading and related } \\
\text { organizations). }\end{array}$ \\
\hline
\end{tabular}




\begin{tabular}{|c|c|}
\hline $\begin{array}{l}\text { Lack of strategy for the introduction of } \\
\text { BIS }\end{array}$ & $\begin{array}{l}\text { Raising the awareness of the fact that the } \\
\text { implementation of BIS for the specific } \\
\text { organization is a unique process and it is } \\
\text { necessary to adopt a comprehensive } \\
\text { approach for adaptation and integration of } \\
\text { BIS to the existing ICT system of the } \\
\text { enterprise. }\end{array}$ \\
\hline $\begin{array}{l}\text { Ignorance and underestimation of } \\
\text { possible threats, obstacles and restrictions } \\
\text { for BIS implementation }\end{array}$ & $\begin{array}{l}\text { Getting acquainted with performed } \\
\text { analyses, research and statistics on the } \\
\text { issue. Comparing the experience of } \\
\text { related organizations. Incorporating the } \\
\text { information received into the BIS strategy } \\
\text { in order to minimize costs and overcome } \\
\text { the risk of failure. }\end{array}$ \\
\hline $\begin{array}{l}\text { Managers' insufficient knowledge of the } \\
\text { processes of BIS implementation }\end{array}$ & $\begin{array}{l}\text { Searching for comprehensive sources, } \\
\text { getting acquainted with and analyzing } \\
\text { individual verified, reliable and quality } \\
\text { sources. }\end{array}$ \\
\hline $\begin{array}{l}\text { Lack of suitable consultants for BIS } \\
\text { implementation }\end{array}$ & $\begin{array}{l}\text { Contacting recommended appropriate } \\
\text { external consultants. Training their own } \\
\text { in-house staff. }\end{array}$ \\
\hline Too expensive consulting services & $\begin{array}{l}\text { Minimizing the time and increasing the } \\
\text { efficiency of the consultations. Training } \\
\text { their own in-house staff and maintaining } \\
\text { their high qualification with periodic } \\
\text { training. }\end{array}$ \\
\hline $\begin{array}{l}\text { Insufficient staff for the introduction and } \\
\text { maintenance of BIS }\end{array}$ & $\begin{array}{l}\text { Recruiting qualified IT staff. Contacting } \\
\text { recommended appropriate external } \\
\text { consultants. }\end{array}$ \\
\hline $\begin{array}{l}\text { Insufficient competence and } \\
\text { qualification of the staff }\end{array}$ & $\begin{array}{l}\text { Organizing participations and appropriate } \\
\text { forms of training (specialized courses, } \\
\text { master classes, workshops, business } \\
\text { games, simulations, etc.). Conducting } \\
\text { staff certification. }\end{array}$ \\
\hline $\begin{array}{l}\text { Too expensive staff training and } \\
\text { certification }\end{array}$ & $\begin{array}{l}\text { Certifying a small number of specialists } \\
\text { to train other employees and to participate } \\
\text { in all stages of project development and } \\
\text { implementation. }\end{array}$ \\
\hline Lack of support from functional units & $\begin{array}{l}\text { Mandatory involvement of appropriate } \\
\text { employees from all functional } \\
\text { departments in the discussion of the } \\
\text { concepts, formation and implementation } \\
\text { of the BIS strategy. Overcoming the } \\
\text { internal resistance of employees by } \\
\text { jointly discussing and explaining the }\end{array}$ \\
\hline
\end{tabular}




\begin{tabular}{|c|c|}
\hline & $\begin{array}{l}\text { concepts, goals, processes, activities, } \\
\text { roles and responsibilities. }\end{array}$ \\
\hline Internal resistance of IT employees & $\begin{array}{l}\text { Explaining the benefits of the } \\
\text { implementation of BDS, as well as the } \\
\text { possible harms of its non-implementation. } \\
\text { Stimulating and motivating employees } \\
\text { for the process of implementation, use } \\
\text { and development of BIS. Proper } \\
\text { distribution of roles among employees. } \\
\text { Creating a BIS culture in the IT } \\
\text { department. }\end{array}$ \\
\hline $\begin{array}{l}\text { Lack of a balanced and skillful project } \\
\text { team }\end{array}$ & $\begin{array}{l}\text { The composition and skills of the BI team } \\
\text { have a great influence on the success of } \\
\text { the BIS implementation project and the } \\
\text { satisfaction with its use. Selecting team } \\
\text { members so that they will work together } \\
\text { in the most effective way possible. }\end{array}$ \\
\hline $\begin{array}{l}\text { Lack of trust between the employees in } \\
\text { the separate functional divisions and the } \\
\text { managing units }\end{array}$ & $\begin{array}{l}\text { Joint discussion and explanation of } \\
\text { concepts, goals, processes, activities, } \\
\text { roles and responsibilities. Explaining the } \\
\text { benefits of implementing BIS. } \\
\text { Demonstrating a specific application in a } \\
\text { selected functional unit. }\end{array}$ \\
\hline $\begin{array}{l}\text { Lack of a suitable ICT system in the } \\
\text { enterprise }\end{array}$ & $\begin{array}{l}\text { The overall strategy for BDS } \\
\text { implementation should also include the } \\
\text { construction of basic IC facilities } \\
\text { necessary for the proper functioning of } \\
\text { BIS. }\end{array}$ \\
\hline $\begin{array}{l}\text { Lack of analysis of the state of an existing } \\
\text { ICT system }\end{array}$ & $\begin{array}{l}\text { Performing an IT analysis showing the } \\
\text { current state of the ICT system - its } \\
\text { capabilities and disadvantages, such as: } \\
\text { ease of use, functionality, reliability, } \\
\text { flexibility, and response time. Possibility } \\
\text { for integration with the BIS selected for } \\
\text { implementation. }\end{array}$ \\
\hline Badly supported ICT system & $\begin{array}{l}\text { Consulting an IT specialist on the } \\
\text { adoption of measures for the appropriate } \\
\text { renewal of the existing ICT in order to } \\
\text { ensure the proper functioning of BIS. }\end{array}$ \\
\hline Too expensive implementation & $\begin{array}{l}\text { Gradual implementation. Creating a long- } \\
\text { term program of projects. Proper } \\
\text { definition of the scope, processes, } \\
\text { activities, elements and priorities of the } \\
\text { system. Allocating time, human and } \\
\text { financial resources. }\end{array}$ \\
\hline
\end{tabular}




\begin{tabular}{|c|c|}
\hline $\begin{array}{l}\text { Too much complexity of the processes } \\
\text { related to the implementation of BIS }\end{array}$ & $\begin{array}{l}\text { Creating and maintaining a multi-layered } \\
\text { model for managing the BI system, } \\
\text { consisting of its description on a } \\
\text { conceptual, logical and physical level. } \\
\text { Ways to overcome the complexity - } \\
\text { breaking it down, setting priorities, } \\
\text { phasing in funding and implementation. }\end{array}$ \\
\hline Expensive ready effective solutions & $\begin{array}{l}\text { Assessing their own possibilities for } \\
\text { acquiring a ready solution. Calculating } \\
\text { the return on investment indicators. } \\
\text { Evaluating the effectiveness of the ready } \\
\text { solution and analyzing the feedback for } \\
\text { its practical use. Purchasing parts of } \\
\text { individual modules according to the } \\
\text { established strategy. }\end{array}$ \\
\hline Too long implementation period & $\begin{array}{l}\text { Systematizing the individual units } \\
\text { responsible for the implementation and } \\
\text { compliance with the strategy for BIS } \\
\text { integration. Managing the awareness of } \\
\text { individual units and the subsequent } \\
\text { implementation. Creating a program of } \\
\text { projects, synchronizing the activities at } \\
\text { the different stages of implementation and } \\
\text { elements of BIS. }\end{array}$ \\
\hline $\begin{array}{l}\text { Providing support / service of the } \\
\text { implemented BIS }\end{array}$ & $\begin{array}{l}\text { Providing support for the implemented } \\
\text { BIS by qualified employees. Creating a } \\
\text { service culture in the organization. If } \\
\text { necessary, using external consultants. }\end{array}$ \\
\hline
\end{tabular}

However, despite the problems and challenges discussed above, the author agrees with Jones and Van (2010), who emphasized that the benefits of BI for the business far outweigh the costs, stating that BI can be the differentiating factor in the market during periods of poor economy, can facilitate marketing communication plans, and aid in pre-selling an idea to the target customers. In this sense, the statement that "strategic leaders are known for thinking ahead, preparing for succession and implementing strategy" (Stamevska \& Stamevski, 2020) suggests that Bulgarian SME managers need to rethink and adopt a comprehensive strategy for the application of intelligent technologies for business analysis. Such a strategy can be considered to be the key to improving the ICT of the enterprise. It can become a source of innovative growth and give a strong impetus to the development of organizations, giving them priorities for positioning and expanding the market of manufactured goods and services, as well as for achieving higher competitiveness. 


\section{Conclusion}

BIS can be considered to be a key approach for modern Bulgarian small and medium-sized enterprises, which with proper implementation will inevitably lead to sustainable development in the process of monitoring and control of processes related to the processing of large data sets, the extraction of valuable information, and making timely management decisions. Undoubtedly, the implementation of BDS can be seen as a tool for improving the ICT of the enterprise, improving the quality of products and services, reducing costs and increasing the efficiency and effectiveness of the entire organization.

Therefore, the creation of a comprehensive management strategy for the adoption of BIS is of particular importance for Bulgarian small and medium-sized enterprises. It can be seen as a source of innovative growth and can give a strong impetus to the development of the organization. Therefore, it is necessary for SME managers to rethink and adopt a comprehensive strategy for the implementation of BDS, taking into account the most common threats, obstacles and constraints that may have a significant impact on the failure and/or dissatisfaction with the implementation process. An example of this is the difficult choice between the great variety of new platforms and the high dynamics of their generation on the world market, which requires high professional competence and in-depth knowledge of the ICT specifics of the particular enterprise, as well as the willingness of the staff to cooperate in carrying out innovation activities. In addition, the process of BIS implementation is directly related to the existing and operating ICT system in the enterprise. Also, SMEs may face the issue of financial insufficiency for the implementation of BIS and their maintenance. At the same time, with the introduction of BIS, modern companies increasingly tend to look for qualified specialists who have the skills and knowledge to work with software platforms and technologies for in-depth multi-dimensional analysis, but they are difficult to find on the market.

\section{Future Studies}

The performed analysis is a logical basis for a future in-depth study of the current state of the BDS used in Bulgarian small and medium-sized enterprises. 


\section{REFERENCES}

Clark, T. D., Jones, M. C., Armstrong, C. P. (2007). The Dynamic Structure of Management Support Systems: Theory development, research focus and directions. MIS Quarterly.

Farrokhi, V., Pokorádi, L. (2012). The necessities for building a model to evaluate Business Intelligence projects- Literature Review. International Journal of Computer Science \& Engineering Survey (IJCSES), vol. 3, pp. 1-10, 2012.

Johns, P., Van, D. (2010). Business intelligence in service marketing: a new approach with practical application. Mark Intell Plan 28(5):551-570.

MicroStrategy. (2013). Architecture for Enterprise Business Intelligence. Available

at: https://www.microstrategy.com/Strategy/media/downloads/whitepapers/MicroStrategy-Architecture-for-Enterprice.pdf

Neykova, M., \& Miltchev, R. (2019) Conceptual approach to introduce an integrated model improving SMEs e-business technologies. Management Theory and Studies for Rural Business and Infrastruc-ture Development, 41(3), 381-399, https://doi.org/10.15544/mts.2019.31

Shariat, M., \& Hightower Jr, R. (2007). Conceptualizing business intelligence architecture. Marketing Management Journal, 17(2), 40-46.

Stamevska, E., Stamevski, V. (2020) Decisions and skills of the strategic leaders. Economics and Management, Volume: XVII, Issue: 1, pp. 140-146. ISSN: 2367-7600.

Available

at: http://em.swu.bg/images/SpisanieIkonomikaupload/SpisanieIkonomika2020 I_vol.XVII_issue_1_2020-140-146.pdf

UL-Ain, N., Giovanni, V. \& DeLone, W. (2019). Business intelligence system adoption, utilization and success - A systematic literature review, Proceedings of the 52nd Hawaii International Conference on System Sciences, January 8 - January 11, 2019, Grand Wailea, Maui.

Watson, H. J., \& Wixom, B. H. (2007). The current state of business intelligence. Computer, 40(9), 96-99.

Yeoh, W., \& Koronios, A. (2010). Critical success factors for business intelligence systems. Journal of computer information systems, 50(3), 23-32. 